\title{
Cloning and Sequencing of a Coleopteran specific Novel cry gene of a local isolate of Bacillus thuringiensis
}

\author{
Kausar Malik* and Mir Muhammad Ali Talpur \\ Lahore College for Women University, Lahore. \\ Department of Microbiology, Shah Abdul Latif University, Khairpur Mir's.
}

\begin{abstract}
A cry gene, obtained from a locally isolated Bt. strain, CAMB \# 30382 (isolated from grain dust of Shakargarh, Punjab, Pakistan), highly effective against Tribolium castaneum (Commonly known as red flour beetle), was amplified through Polymerase chain reaction (PCR) by using specific primers. The gene was ligated to a cloning vector PGEM-T and was cloned into an E.coli strain DH5 $\alpha$. The positive clones were screened for the cry gene content.

The partial sequencing of the cloned gene from this strain was accomplished and sequence homology was analyzed. The alignment of the sequenced gene with gene sequences present in gene data bank showed two silent mutations, at nucleotide 676 and 701. However, two other nucleotide changes at position 2887 and 2902 of holotype cryIIIf (cry8Ca) gene were resulting from amino acid change near 3' end were observed. These changes were causing change in the stretch of amino acids from valine, tyrosine, serine \& glutamine in the holotype cryIIIf to glycine, phenylalanine, alanine \& asparginine respectively in the clone from CAMB isolate 30382. This change may have drastic effect on the toxicity spectrum of the Cry protein isolated from this local isolate in comparison with the Cry protein from the Buibui. serovar japonesis. Partial sequencing has shown it to be a varient of cryIII gene, which may be a novel cry gene.
\end{abstract}

Key Words; Cloning, Bacillus thuringiensis, cry gene, Sequencing, Coleopteran.

\section{Introduction}

Bacillus thuringiensis is a gram-positive bacterium, widely used in agriculture as a biological pesticide. The protein inclusion is composed of one or more types of delta-endotoxins Cry and Cyt proteins. Many Bacillus thuringiensis with different host spectra have been identified (Burges 1981). The delta-endotoxins are mostly used in agriculture by organic and other growers to control agronomically important pests (Dulmage 1981; Guillet et al., 1990; and Mulla 1990).

Bt. produces several insecticidal crystalline proteins (ICP/Cry proteins) at the time of sporulation. The $\beta$-exotoxins and $\delta$-endotoxins are used for the control of pests and vectors of diseases. The crystalline delta endotoxins are predominantly synthesized as long, inactive protoxins that are activated by proteolysis in the insect gut. The examples include Cry 1, Cry4A, Cry4B, having molecular weights of 130 to $140 \mathrm{kDa}$ are processed Bacillus thuringienesis to active 65 to $70 \mathrm{kDa}$ toxins (Gill et al., 1992,; Hofte and whitely; 1989) while Cry2A, Cry3A, Cry10A and Cry11A are naturally truncated toxins with molecular weights ranging from 65-80 kDa. Sequence analyses of many genes have suggested that significant changes in the activity spectrum can be attributed to comparatively small changes in amino acid sequences (Rahat 1998).

The red flour beetle, Tribolium castaneum is an important pest of stored grains. These beetles live mainly in grain store mills and bird nests (Roth and Kurtz 2008). Both Larvae and adults of the red flour beetle feed on broken kernels and grain dust. These stored pests are mostly get rid of in the house in infected cereal or flour while some red flour beetles survive on food material in cervices, furniture and cabinet cracks and can increase their descendents (Haque et al., 2000).

Bacillus thuringienesis contain valuable environment-proteins of cry genes. So it is considered as friendly bio pesticide, which constitutes $90 \%$ of the world significance by production of resistant crops, such bio pesticide commercially. Its insecticidal properties were analyzed against maize, cotton, potato,rice etc (Kumar 2002).

Incorporation of Bt technology into an integrated pest management is the preferred strategy to achieve effective insect control while minimizing target resistance (Andow et al., 2001).

To increase the effacacy and persistance of Bt. toxins for field use, crystal proteins genes (cry genes) have been cloned and expressed in E. coli, Bacillus subtitles, Pseudomonas fluorescens, Clavibacter, Baculovirus and nuclear polyhedrons virus (Haider and Ellar, 1988; Hofte et al.,1987; Honee et al.,1988; Sen et al.,1988; Ge et al.,1990; Merryweather et al.,1990; Martins et al.,1990)

The first cloning of Cry IAa gene from Bacillus thuringiensis subsps. kurstaki was reported by Schenpf and Whiteley 1981.It has been established that the delta-endotoxin genes whose products are specifically active on different orders of insects show only limited similarity and are distantly related (Hernest et al., 1986). . 
The cryIIIA gene was cloned and sequenced by Sekar et al., 1987 and Mc Pherson et al., 1988 from Bt. var tenebrionis, which showed 69 percent homology with cry IIIB gene from Bt. var tolworthi (Sick et al., 1990).

\section{bacterial strains and media}

\section{Material And Methods}

Based on molecular characterization, a Bacillus thuringiensis strain C.E.M.B 30382, containing cryIII gene, highly effective against Tribolium casatenium was isolated and selected for gene cloning and sequencing. The Bt. strain isolated from the local environment was cultivated in S.P.Y medium having the composition in $\mathrm{g} / \mathrm{l}$ : ammonium sulphate 20 , potassium dihydrogen phosphste 6 , dipotassium hydrogen phosphate 14 , sodium citrate 1 , magnesium sulphate 0.29 , yeast extrat 1 and glucose (sigma) 6 was used as a carbon source.

E.coli strain DH5-alpha was chosen as recipient strain and grown in LB medium containing g/l: tryptone (Difco) 10.0, Yeast extract (Difco) 5.0, $\mathrm{NaCl} 10.0$, and ampicillin $50 \mathrm{ug} / \mathrm{ml}$ at $30^{\circ} \mathrm{C}$ for 24 hours.

\section{DNA isolation and gene identification}

To isolate and identify the gene of interest, the total genomic DNA was isolated by the method of Kronstad et al., (1983), (fig 1). An overnight culture from a single colony of bacterial cells was diluted in SPY medium in $1: 100$ ratio. Cells were grown at $35^{\circ} \mathrm{C}$ with shaking to optical density 0.8 at $600 \mathrm{~nm}$ in 2.8 Litre flask with shaking $200 \mathrm{rpm}$. Cells were harvested by centrifugation at $4^{\circ} \mathrm{C}$ at $7 \mathrm{~K} \mathrm{rpm}$ for $10 \mathrm{~min}$. The cell pellet was washed with solution containing $100 \mathrm{mM}$ Tris- $\mathrm{HCl}(\mathrm{pH} 7.9)$ and $10 \mathrm{mM}$ EDTA. Lysozyme was added to give a concentration of $0.5 \mathrm{mg} / \mathrm{ml}$. Mixture was incubated at $37^{\circ} \mathrm{C}$ for 20 minutes. $6.25 \mathrm{ml}$ of solution containing 100 $\mathrm{mM}$ tris- $\mathrm{HCl}(\mathrm{pH} \mathrm{7.5),} 100 \mathrm{mM} \mathrm{NaCl}$ and 2\% SDS was were added to lyse the cells. Preparation was mixed by gently inverting the tubes several times. Incubation was given at $60{ }^{\circ} \mathrm{C}$, till the preparation was clear. Extraction was done with Phenol-Chloroform mixture. Aqueous layer was removed with the wide bore pippette. 2.5 volume of chilled Ehanol was added and DNA was spooled out with a glass rod. DNA was rinsed with $70 \%$ Ethanol, air dried and resuspended in $500 \mathrm{ul}$ to $1 \mathrm{ml}$ of T.E (10mM Tris-HCL pH 7.9,1mM EDTA). DNA was dialyzed extensively against cold TE buffer at $4^{\circ} \mathrm{C}$ and concentration measured by taking O.D.260.

\section{Gene amplification through Polymerase Chain Reaction}

To amplify the gene of interest, Polymerase Chain reaction was done by a modification by saiki et.al., (1988). A total volume of $50 \mathrm{ul}$ contained $2.5 \mathrm{mM} \mathrm{MgCl} 2,10 \mathrm{mM}$ tris- $\mathrm{HCl} \mathrm{pH} \mathrm{8.0,100} \mathrm{uM} \mathrm{of} \mathrm{each}$ deoxyribonucleotide triphosphate (dNTPs), $50 \mathrm{pmol}$ of each forward and reverse primer, one unit Taq DNA polymerase and 5-100 ng of DNA template. Overlaid 50-ul light mineral oil on the reaction mixture. The mixtures were amplified in 35 cycles by programming the PCR machine ( $\mathrm{M} \mathrm{J}$ research) according to the expected length of the PCR product.

To amplify $3.4 \mathrm{kbps}$, DNA fragment from the genomic DNA of isolate 30385, the PCR programme was as follows:

\begin{tabular}{|c|c|}
\hline$\frac{1 \text { Cycle }}{95^{\circ} \mathrm{C}}$ & \\
\hline $35 \mathrm{Cycl}$ & \\
\hline & 1 minut \\
\hline & \\
\hline & $4 \mathrm{minu}$ \\
\hline ycle & \\
\hline & $1 \mathrm{~min}$ \\
\hline & \\
\hline
\end{tabular}

Once the PCR reaction was complete, it was kept at $4^{0} \mathrm{C}$ till further processing.

\section{Purification of DNA fragments}

DNA fragments were isolated from the agarose gel using Qiaquick gel extraction kit (cat \#28704). The specific DNA samples were run through $1 \%$ agarose gel. The required fragment of $3.48 \mathrm{~kb}$ was cut out of the gel under UV light (by using UV transilluminator), and transferred to an eppendorf tube. The gel slice was weighed and three times volume of buffer QG was added from the kit. In addition it was incubated at $50 \mathrm{C}$ in a water bath for approximately 10 minutes. Now added equal volume of isopropanol and mixed gently. Applied this mixture to Qiaquick column and centrifuged for 1 minute. Discarded the flow through and added $0.75 \mathrm{ml}$ buffer PE (wash buffer) to the column and centrifuged for 1 minute. Discarded the flow through and eluted the DNA bound with column, with 33-50-ul water. 


\section{Plasmid DNA Isolation.}

Plamid DNA was isolated by alkaline lysis method (Brinboin and Dolly, 1979). Single bacterial colony was used to inoculate $5 \mathrm{ml}$ of LB medium containing the antibiotic ampicillin and grown at $35{ }^{0} \mathrm{C}$ with vigorous shaking for 12-16 hours (overnight). $1.5 \mathrm{ml}$ of overnight culture was shifted to a micro centrifuge tube and centrifuged at $12000 \mathrm{rpm}$ for 3 minutes. The supernatant was decanted and the pellet was re-suspended in $100 \mathrm{ul}$ of ice cold cell suspension buffer (25M Tris Hcl pH 8.0,10 mM EDTA, 50mM glucose, $2 \mathrm{mg} / \mathrm{ml}$ lysozyme) and incubated for 5 minutes. Then 200 ul of a freshly prepared cell lysis solution (1\% SDS, $0.2 \% \mathrm{NaOH})$ was added. After immediately mixing by inverting the tube several times and $5 \mathrm{~min}$. incubation of lysate at room temperature, $150 \mathrm{ml}$ of ice-cold $3 \mathrm{M}$ potassium acetate solution ( $\mathrm{pH} \mathrm{4.8)}$ was added and again mixed by inversion followed by 15 minutes incubation on ice. Centrifugation was done at $12000 \mathrm{rpm}$ for 15 minutes and clear supernatant was extracted with an equal volume of Phenol: Chloroform: Isoamylalcohol (25:24:1) mixture. Extracted aqueous phase was carried out at $-20{ }^{0} \mathrm{C}$ for 15 minutes followed by centrifugation at $12000 \times \mathrm{xg}$ for 15 minutes. The pellet was rinsed with ice-cold 70\% Ethanol, air dried and re-suspended in 25 ul of nuclease free water.

\section{Automated DNA sequencing}

Automated DNA sequencing (ABI) from Applied Biosystems was used along with ABI PRISM Ready reaction DyeDeoxy terminator sequencing Kit according to manufacturer's instructions. This method is based on dye terminator chemistry, in which each of the four dideoxynucleotides is labeled with a different flourochrome (Prober et al., 1987; Lee et al., 1992). The ABI 377 can simultaneously detect fluorescence at four different wave lengths, set to coincide with the emission of four different fluorescent dyes. The reaction mixture is run in a single capillary so that color of each band is passing the detector represents the DNA sequences.

Performing the sequences reaction simply required the mixing of DNA $(0.8 \mathrm{ug})$, primer $(\sim 3.2 \mathrm{pmol})$ and water with an aliquot of premixed reagents from the kit followed by 25 cycles in a thermal cycler (Perkin-Elmer). The unincorporated, labeled nucleotides were removed by ethanol precipitation and the samples air dried. Just prior to gel electrophoresis, the sample was re-suspended in a gel loaded buffer (TSR Template Solubilizing Reagent) and heated to denature the DNA.

The raw sequence data collected by the system were processed by associated software to get an electropherogram and finally the DNA sequence in the text form.

\section{Homology Studies of Sequenced Nucleotides}

Homology studies of the nucleotide sequences of the clones with known nucleotide sequences present in gene data bank was done through standard nucleotide-nucleotide BLAST (Basic Local Alignment Search Tool) software available at NCBI website.

www.ncbi.nlm.gov/home/Blast

Nucleotide sequences were put in FASTA format and a non redundant search was conducted. The results were obtained at HTML document showing the statistical score values for homology along with nucleotide to nucleotide homology.

\section{Electro competent Cell Preparation}

A single colony from freshly growing plate was inoculated into $5 \mathrm{ml}$ of LB medium and grown with vigorous shaking at 37C until O.D was 0.8 at 550nm. Cells were harvested by centrifugation and pellet washed twice by re-suspension in ice-cold $10 \%$ sterile glycerol in sterilized de-ionized water. The cell pellet was then re-suspended in $1 \mathrm{ml}$ of $10 \%$ glycerol to bring the final cell density to 200-250 O.D 550 units. Cells were aliquoted in $100 \mathrm{ul}$ aliquots and stored at $-70 \mathrm{C}$.

\section{Cloning procedure}

Total genomic DNA, isolated from the Bt. strain 30382, was used to amplify a $3.48 \mathrm{kbp}$ full length cry3 type gene by using specific primers. Ligation of the amplified fragments was done in pGEM-T vector according to the instructions supplied with kit (Promega). The ligation mixture contained $11 \mathrm{ul}$ sample containing $60 \mathrm{ng}$ of vector, $180 \mathrm{ng}$ of insert and $5 \mathrm{ul}$ of Buffer (Progema). Ligation reaction was achieved with 3 units of T4 DNA ligase (Promega) at $16 \mathrm{C}$ for 24 hours. The E.coli DH5 $\alpha$ (alpha) was used for high ligation mixture transformations. For the transformation of ligated DNA, the ligation mixture was ethanol precipitated, washed with $70 \%$ ethanol, dried and resuspended in $5 \mathrm{ul}$ of ionized water. Half of the resuspended ligation mixture was used in electroporation of 100 ul of DH5 $\alpha$ cells. Pulse for electroporation was given at $2.5 \mathrm{~K}$. V voltage, $200 \mathrm{ohms}$ resistance \& $25 \mu \mathrm{F}$ capacitance. After electroporation, cells were immediately shifted to SOC Medium $(\mathrm{MgCl} 2.6 \mathrm{H} 2 \mathrm{O}, \mathrm{MgSO} 4.7 \mathrm{H} 2 \mathrm{O})$ \& grown for 1 hour. The transformants were selected on LB agar plates containing X-gal, IPTG, at $40 \mathrm{ug} / \mathrm{ml}$ concentration each and Ampicillin at the concentration of $100 \mathrm{ug} / \mathrm{ml}$ for Blue/white colony selection. White colonies analyzed contained the recombinant plasmid. The positive 
clones were also confirmed through PCR amplification using forward and reverse primers. The positive clones were also confirmed through restriction digestion with EcoR I enzyme.

\section{Results}

To isolate and identify the gene of interest, the total genomic DNA was isolated by the method of Kronstad et al., (1983), (fig 1).

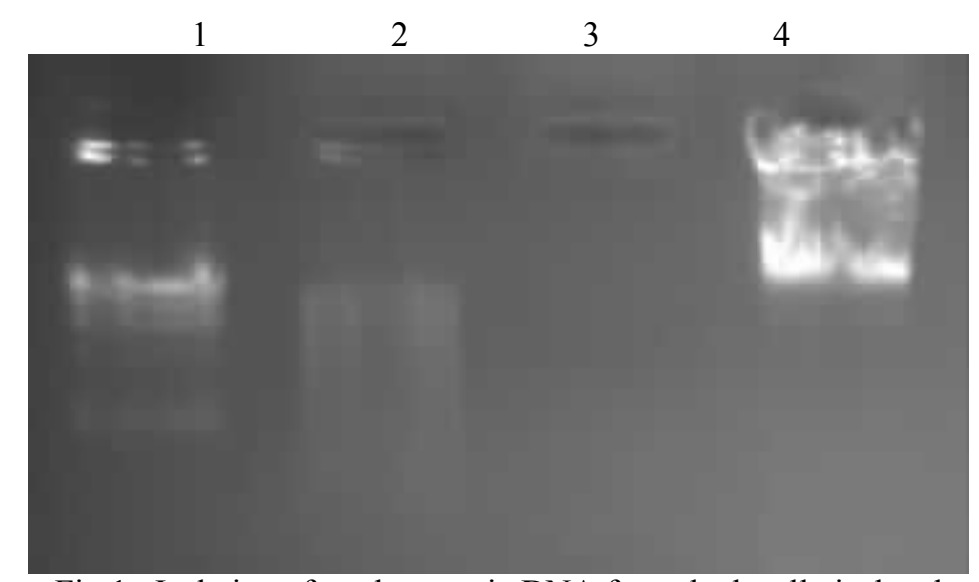

Fig 1.: Isolation of total genomic DNA from the locally isolated

Bt strain 30382. Lane 1. : $\lambda /$ hind III marker, Lane 2; genomic DNA subjected to the restriction, Lane3;-ve control, Lane 4; +ve control.

To amplify the gene of interest, Polymerase Chain reaction was done by a modification by saiki et.al., (1988).

$1 \quad 2 \quad 3$

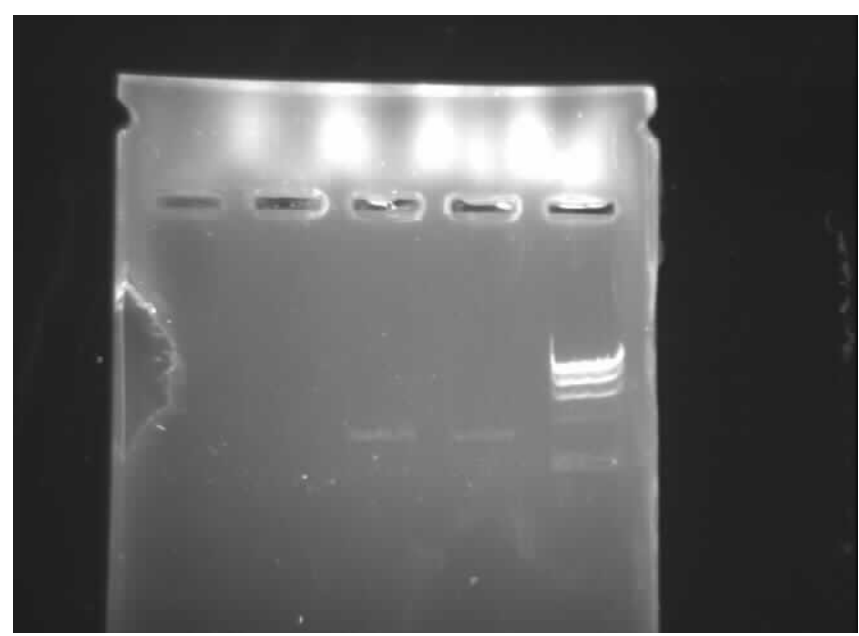

$3.4 \mathrm{~kb}$

Figure 2: PCR amplification of cry3 gene, using specific primers, from the isolated genomic DNA..

Lane1 \& 2: amplified $3.4 \mathrm{~kb}$ cry3 gene. Lane3: $\lambda$ Hind III DNA Marker.

For cloning of the delta- endotoxin gene a complete coding sequence including initiations as well as termination codons was amplified. A number of PCR reactions were performed. The PCR product was run through agarose gel. The $3.4 \mathrm{~kb}$ fragment was eluted from gel using DNA purification kit (QIAGEN). PCR product was cloned in pGEMT vector (Promega) (Fig3), specially designed for cloning of the PCR products with A-overhanging at $5^{\prime}$ terminal. Ligation was followed by transformation through electroporation in E.coli strain DH5a. Transformants were selected on LB agar plates which contained ampicillin $(100 \mathrm{ug} / \mathrm{ml}), \mathrm{X}$-gal $(40 \mathrm{ug} / \mathrm{ml})$, and IPTG (40ug/mg), for blue/white colony selection. 


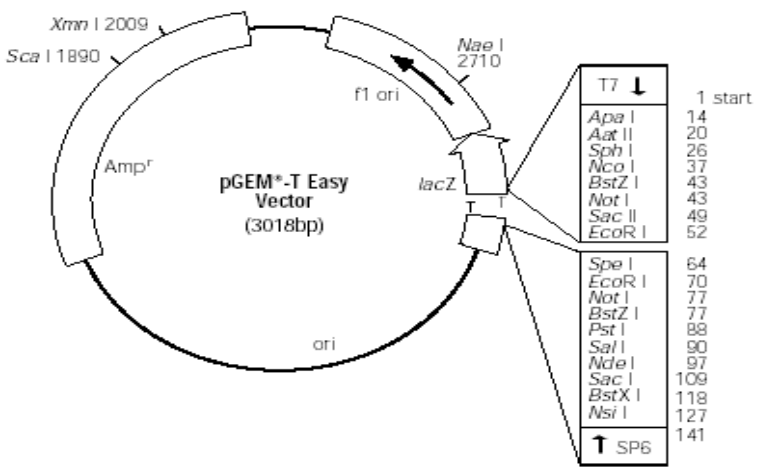

Fig: 3. Restriction map of pGEM-T vector, showing restriction sites for EcoR1.

The positive clones were also confirmed through PCR amplification using forward and reverse primers. The positive clones were also confirmed through restriction digestion with EcoR I enzyme (fig 4). White colonies analyzed contained recombinant plasmids. Positive clones were confirmed by PCR amplification of the gene cloned, using reverse and forward primers (Fig 4). The positive clones were also confirmed through restriction digestion with EcoR1.

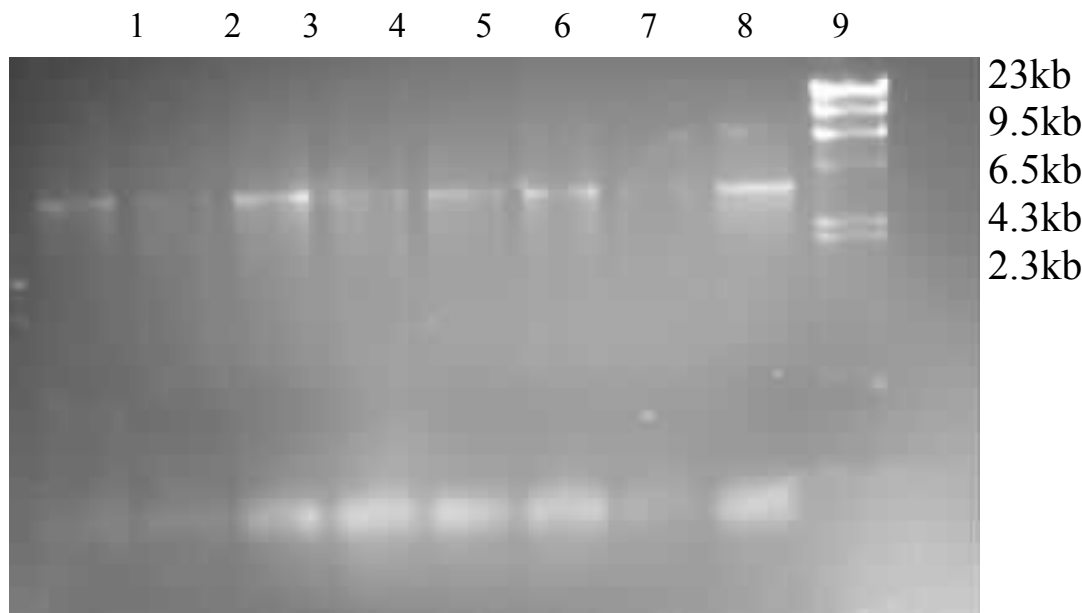

Fig 4: Confirmation of cry3 gene within the clones through PCR, using specific primers. Lane 1-8, amplified $3.4 \mathrm{~kb}$ cry3 gene, Lane $9: \lambda /$ hind III marker

The DNA from a selected clone was used as a template with 2 oligonucleotide primers for the full length sequencing of the gene through automated DNA sequencing system. The nucleotide sequence comparison of the cloned gene with cry3f gene sequence present in gene data bank (Gene bank Accession number U04366) showed homology between two genes with some significant nucleotide changes. Homology study studies of the sequencing data with the gene sequences present in gene data bank showed that it was a variant of a novel CryIII protein gene reported by Sato et al. (1994).

POF1: 1 taatcaaaatgagtatgaaattatagatgetttatcacccacttctgta

U04366 1 atgagtccaaataatcaaaatgagtatgaaattatagatgctttatcacccacttctgta

PCF1: 51 tccgataattctattagatatcetttagcaaacgatcaaacgaacacattacaaaacatg

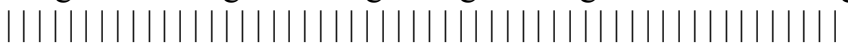

U04366 61 tccgataattctattagatatcctttagcaaacgatcaaacgaacacattacaaaacatg

PCF1: 111 aattataaagattatctgaaaatgaccgaatcaacaaatgctgaattgtctcgaaatccc

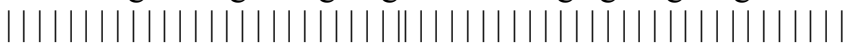

U04366 121 aattataaagattatctgaaaatgaccgaatcaacaaatgctgaattgtctcgaaatccc

PCF1: 171 gggacatttattagtgcgcaggatgeggttggaactggaattgatattgttagtactata

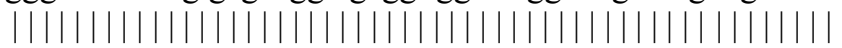

U04366 181 gggacatttattagtgcgcaggatgcggttggaactggaattgatattgttagtactata

PCF1: 231 ataagtggtttagggattccagtgcttggggaagtcttctcaattctgggttcattaatt 
PCF1: 291
004366 301 gg
PCFl: 351
U04366 361
PCF1: 411

U004366 421

PCF1: 471

U04366 481

PCF1: 531

U04366 541

PCF1: 591

U04366 601

U04366: 651 tggggatatcctctaaaatgatattgacctattttataaacaacaagtatcttatacggct |||||||||||| ||||||||||||||||||||||| |||||||||||||||||||

U04366 661 tggggatatcctcaaaaatgatattgacctatttataaataacaagtatcttatacggct 720

PCF1: 711 agatattccgatcattgcgtocaatgqtacaatgctggtttaaataaattaagaggaacg 770

U04366 721

PCF1:

U04366 781

PCF1:

004366841

PCF1:

U04366901

PCF1:

004366961

PCF1:

U04366 1021

PCF1:

U04366 1081

PCF1:

U04366 1141

PCF1:

U04366 1201

PCF1:

U04366 1261

PCF1:

0043661321

PCF1:

U04366 1381

PCF1:

U04366 1441

PCF1:

U04366 1501

PCF1:

U04366 1561

PCF1:

U04366 1621

PCF1:

U04366 1681

PCF1:

|| ||||||||||||||||||||||||||||||||||||||||||||||||||||

gcttattgtggccgtcaaataatgaaaatgtatggcaaatatttatgaatcgagtggaa $\quad 360$

gagctaattgatcaaaaaatattagattctgtaagatcaagagccattgcagatttagct 410

|| || ||||||||||||||||||||||||||||||||||||||||||||||||||||

gagctaattgatcaaaaaatattagattctgtaagatcaagagccattgcagatttagct 420

aattctagaatagctgtagagtactatcaaaatgcacttgaagactggagaaaaaccca 470

|| |||||||||||||||||||||||||||||||||||||||||||||||||||||||||

aattctagaatagctgtagagtactatcaaaatgcacttgaagactggagaaaaaaccca 480

cacagtacacgaagcgcagcacttgtaaaggaaagatttggaaatgcagaagcaatttta

|| |||||||||||||||||||||||||||||||||||||||||||||||||||||

cacagtacacgaagcgcagcacttgtaaaggaaagatttggaaatgcagaagcaatttta

cgtactaacatgggttcattttctcaaacgaattatgagactccactcttaccacatat 590

||||||||||||||||||||||||||||||||||||||||||||||||||||||

cgtactaacatgggttcattttctcaaacgaattatgagactccactcttaccoacatat 600

gcacaggccgcetctctgcatttgcttgtaatgagggatgttcaaatttacgggaaggaa 650

|| |||||||||||||||||||||||||||||||||||||||||||||||||||||

gcacaggccgcctctctgcatttgcttgtaatgagggatgttcaaatttacgggaaggaa 660

||||||||||||||||||||||||||||||||||||||||||||||||||||||||

agatattccgatcattgcgtocaatggtacaatgctggtttaaataaattaagaggaacg 780

ggtgctaagcaatgggtggattataatcgtttccgaagagaaatgaatgtgatggtattg 840

gatctagttgcattatttccaaactacgatgcgcgtatatatccactggaaacaaatgca 900

gaacttacaagagaaattttcacagatcctgttggaagttacgtaactggacaatcgagt 960

accettatatcttggtacgatatgattccagcagctcttccttcattttcaacgctcgag

1020

aacctacttagaaaacctgatttctttactttgctgcaagaaattagaatgtatacaagt

1080

tttagacaaaacggtacgattgaatattataattattggggaggacaaaggttaaccett

1140

tcttatatctatggttcctcattcaataaatatagtggggttcttgccggtgctgaggat

1200

attattcctgtgggtcaaaatgatatttacagagttgtatggacttatataggaaggtac

1260

acgaatagtctgctaggagtaaatccagttactttttacttcagtaataatacacaaaaa

1320

acttattogaagccaaaacaattcgcgggtggaataaaaacaattgattccggcgaagaa

1380

ttaacttacgaaaattatcaatcttatagtcacagggtaagttacattacatcttttgaa

1440

ataaaagtaccggtggtacagtattaggagtagttcctatatttggttggaogcatagt

1500

agtgccaqtcgcaataactttatttacgcaacaaaaatctcacaaatcccaatcaataaa

1560

gcaagtagaactagcggtggagcggtttggaatttccaagaaggtctatataatggaqga

1620

cctgtaatgaaattatctgggtctggttccaagtaataaacttaagggtcgcaacaqat $\quad 1680$

gcaaagggagcaagtcaaagatatcgtattagaatcagatatgcctctgatagagcgggt 1740 
U04366 1741 aaatttacgatatcttccagatctccagagaatcctqcaacctattcagcttctattgct $\quad 1800$

PCF1:

U04366 1801 tatacaaatactatgtctacaaatgcttctctaacgtatagtactttgcatatgcagaa $\quad 1860$

PCF1:

004366 $1861 \quad$ tctggccetataaacttagggatttcgggaagttcaaggacttttgatatatctattaca
PCF1:

U04366 1921 aaagaagcaggtgctgctaacctttatattgatagaattgaatttattccagttaatacg 1980

PCF1:

U04366 1981 ttatttgaagcagaagaagacctagatgtggcaaagaaagctgtgaatggcttgtttacg 2040
PCF1:

U04366 2041 aatgaaaagatgcettacagacaagtgtaacgqattatcaagtcaatcaagcggcaaac 2100

PCF1:

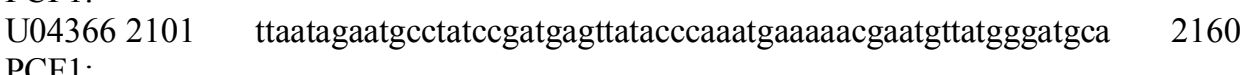

PCF1:

U04366 2161 gtgaaagaggcgaaacgacttgttcaggcacgtaacttactccaagatacaggctttaat

PCF1:

U04366 2221 aggattaatggagaaaacggatggacgggaagtacgggaatcgaggttgtggaaggagat

PCF1:

U04366 2281 gttctgtttaaagatcgttcgcttcgtttgacaagtgcgagagagattqatacagaaaca

PCF1:

U04366 2341 tatccaacgtatctctatoaacaaatagatgaatcgcttttaaaaccatatacaagatat 2400

PCF1:

U04366 2401 aaactaaaaggttttataggaagtagtcaagatttagagattaaattaatacgtcatcgg 2460

PCF1:

U04366 2461 gcaaatcaaatcgtcaaaaatgtaccagataatctcttgccagatgtacgecctgtcaat 2520

PCF1:

$0043662521 \quad$ tcttgtggtggagtcgatcgctgcagtgaacaacagtatgtagacgcgaatttagcactc 2580

PCF1:

U04366 2581

PCF1:

U04366 2641 gatacgggtgaaatagatttgaatgaaaataoaggaatttggatcgtatttaaaattccg

PCF1:

U04366 2701 acaacaaatggaaacgcaacactaggaaatcttgaatttgtagaagaggggccattgtca

PCF1:

0043662761 ggggaaacattagaatgggcccaacaacaagaacaacaatggcaagacaaaatggcaaga 2820

PCF1: 2821

aaacgtgcagcatcagaaaaaacatattatgcagcaaagcaagccattgatcgtttattc

|| ||||||||||||||||||||||||||||||||||||||||||||||||||||||||

U04366 $2821 \quad$ aaacgtgcagcatcagaaaaaacatattatgcagcaaagcaagccattgatcgtttattc

PCF1: 2866 gcagatta-tcaagaccaaaaacttaattctggtgtcgaaatgtcagatttgttggcagcc |||||||| ||||||||||||||||||||||

U04366 2881 gcagattatcaagaccaaaaacttaattctggtgta - gaaatgtcagatttgttggcagc

PCF1: 2926 caaaaccttgtacagtccattccttacgtatataatgatgcgttaccggaaatccetgga 2985

|| || |||||||||||||||||||||||||||||||||||||||||||||||||||||||

U04366 2941 caaaaccttgtacagtccattccttacgtatataatgatgcgttaccggaaatccetgga 3000

|| || || || |||||||||||||||||||||||||||||||||||||||||||||||||

PCF1: 2986 atgaactatacgagttttacagagttaacaaatagactccaacaagcatggaatttgtat 3045

|| || || ||||||||||||||||||||||||||||||||||||||||||||||||||

U04366 3001 atgaactatacgagttttacagagttaacaaatagactccaacaagcatqgaatttgtat 3060

PCF1: 3046 gatcttcaaaacgctataccaaatggagattttcgaaatggattaagtaattggaatgca 3105

|| ||||||||||||||||||||||||||||||||||||||||||||||||||||||||

$\begin{array}{lll}\text { U04366 } 3061 \text { gatcttcaaaacgctataccaaatggagattttcgaaatggattaagtaattggaatgca } & 3120\end{array}$

F1: $3106 \quad$ acatcagatgtaaatgtgcaacaactaagcgatacatctgtccttgtcattccaaactgg 3165

|| || ||||||||||||||||||||||||||||||||||||||||||||||||||||||

U04366 3121 acatcagatgtaaatgtgcaacaactaagcgatacatctgtccttgtcattccaaactgg 3180

PCF1:3166 aattctcaagtgtcacaacaatttacagttcaaccgaattatagatatgtgttacgtgtc 3225

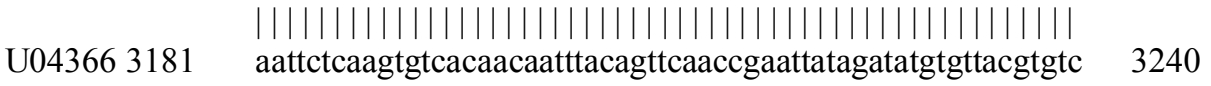




\begin{tabular}{|c|c|c|}
\hline PCF1: 3226 & acagcgagaaaagagggagtaggagacggatatgtgatcatccgtgatggtgcaaatcaq & 3285 \\
\hline U04366 3241 & 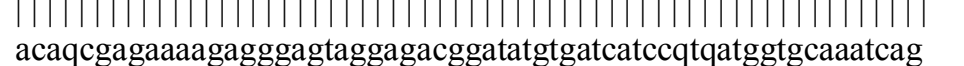 & 3300 \\
\hline PCF1: 3286 & acagaaacactcacatttaatatatgtgatgatgatacaggtgttttatctactgatcaa 3345 & \\
\hline U043663301 & \|\|\|\|\|\|\|\|\|\|\|\|\|\|\|\|\|\|\|\|\|\|\|\|\|\|\|\|$\|$ & 3360 \\
\hline PCF1: 3346 & actagctatatcacaaaaacagtggaattcactccatctacagagcaagtttggattgac 3405 & \\
\hline & 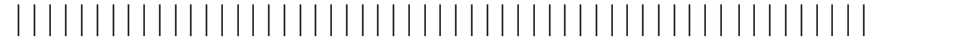 & \\
\hline U04366 3361 & actagctatatcacaaaaacagtggaattcactccatctacagagcaagtttggattgac 3420 & \\
\hline PCF1: 3406 & atgagtgagaccqaaggtgtattcaacatagaaagtgtagaactcgtgttagaagaagag & 3465 \\
\hline & \|\|\|\|\|\|\|\|\|\|\|\|\|\|\|\|\|\|\|\|\|\|\|\|\|\|\|\|\|\|\|\|\|\|\|\|\|\|\|\|\|\| & \\
\hline 0043663421 & atgagtgagaccgaaggtgtattcaacatagaaagtgtagaactcgtgttagaagaagag & 3480 \\
\hline PCF1: $\quad 3481$ & aa 3483 & \\
\hline & || & \\
\hline U04366 3481 & taa 3483 & \\
\hline
\end{tabular}

\section{Discussion}

According to Adang et al. (1993), over 60 cry genes encoding 26 distinct insecticidal crystal proteins have been sequenced, whereas Baum and Malver (1995) found that over 90 ICP genes have now been cloned and sequenced. Thompson et al; (1995) compared the primary sequence of 50 full length toxins and produced a computer-generated dendrogram of possible evolutionary relatedness.

A number of toxin genes effective against lepidopteran, coleopteran and diapteran larvae from different strains of Bt. have been cloned \& expressed in E. coli, Bacillus subtilis, Pseudomonas, clavibacter, Baculovirus, and nuclear polyhederosis virus (Haider et. al., 1988).

Screening for novel activities through biotoxicity assays alone may not be the most effective approach, although in practice worldwide. Since certain cry genes are poorly expressed (or even silent) in their native hosts (Lee and Aronson, 1991; Aronson et al., 1991; Sanchis et al., 1989; Chaambers et al., 1991). Alternative screening methods include southern blotting in search of known homologous genes (Kronstad and Whiteley et al., 1986), analysis of reactivity to different monoclonal antibodies (Hofte et al., 1998) and electrophoretic analysis of PCR products using specific primers (Carozi et al., 1991).

The availability of toxin genes permitted bioassays of individual crystal proteins to study their spectrum of insecticidal without interference from other toxins or other pathogenecity factors (spores, beta exotoxins etc).

The Bacillus thuringiensis strain 30382 was analyzed through gene cloning and sequencing. From the amino acid sequence of that gene, a set of primers was designed to amplify the full length cry gene. The amplified gene was cloned in a cloning vector, pGEM-T. Restriction analysis of the cloned fragment also confirmed the presence of cry3 gene within the clones. Southern blotting of the total DNA from isolate 30382 digested with Hind III enzyme showed that a cry3 type gene was present on approximately $4 \mathrm{~kb}$ fragment.Therefore southern hybridized $4 \mathrm{~kb}$ fragment might be the full length cry3f gene containing promoter, ribosomal binding sites other than regulatory sequences and $5^{\prime} \& 3^{\prime}$ flanking sequences from isolate 30382 . Homology studies of the sequences present in the gene data bank showed it a variant of a novel Cry III protein gene reported by Sato et al., (1994). Homology studies between two nucleotide sequences showed two changes at nucleotide 676 and 701 from 5' end. This change in nucleotide level was not affecting the protein sequence of the gene due to codon degeneracy at amino acid phenylalanine and proline. Two other significant deletion and insertion of nucleotides at position 2888 and 2909 of holotype cry F gene (Genebank Accession \# U04366) near 3 ' end were observed. These changes were causing change in stretch of amino acids from valine, tyrosine, serine, glutamine, in holotype cry3 F to glycine, phenylalanine, alanine, asparginine respectively in the clone from CAMB isolate 30382. This change may have a drastic effect on the toxicity spectrum on the cry protein isolated from the local 30382, in comparison with the cry protein from strain Buibui. serovar japonesis. The cry $3 \mathrm{f}$ gene has been reported to encode proteins of $129 \mathrm{kDa}$, which occurs in Bt. serovar japonesis (Ogiwara et al., 1995). The nucleotide sequencing of the gene cloned in present study was of more interest, hence it may provide more insight into the structure and function of this class of genes, because very small differences in crystal structure, including the presence or absence of protease processing sites, can have deleterious or beneficial effects on the toxicity of molecules (Ward et al., 1988; Haider and Eller 1989; Wu and Aronson1992). Newly found variations may further be helpful to extend the host spectrum of the cryIIIF type gene. 


\section{References}

[1]. Andow, D. A, Huet, A.-S. and Altosaar, I. 2001. An ounce of prevention enough to stem Asia's appetite for rice? Bt rice conference report - Hangzhou, PRC, 27 Nov-1

[2]. Aronson AI, E.-S.,Mcgaughey W and Johnson D. (1991). The solubility of inclusion proteins from Bacillus thuringiensis is dependent upon protoxin composition and is a factor in toxicity to insects. Applied and Environmental Microbiology 57: 981-986.

[3]. Ben-Dov E, Zaritski A. Dahan E, Barak Z, Sinai R, Manasherob R, Khamraev A, Troitskaya E, Dubitsky A, Berezina N and Margalith Y (1997). Extended screening by PCR for seven cry-group genes from field collected strains of Bacillus thuringiensis. Applied and Environmental Microbiology, 63(12) 4883-4890.

[4]. Barton KA, Whiteley HR and Yang NS, (1987). Bacillus thuringiensis delta-endotoxin expressd in transgenic Nicotiana tabaccum provides resistance to lepidopteran insects. Plant Physiology 85: 1103-1109.

[5]. Bhattacharya PR, (2000). Hyper production of Insecticidal crystal protein (delta-endotoxin) by Bacillus thuringienesis var israelensis is not related to sporulation specific biochemical functions Curr. Microbiol, 41 (3): 187-191.

[6]. Birnboim HC and Dolly J, (1979). A rapid alkaline extraction procedure for screening recombinant plasmid DNA. Nucleic acids Research. 7: 1513-1523.

[7]. Burges, H. D. (ed). (1981). Microbiol control of pests and plants diseases 1970-1980. Academic press, Inc. (London), Ltd. London.

[8]. Carozzi NB, Kramer VC, Warren GW, Evola S and Koziel MG, (1991). Prediction of insecticidal activity of Bacillus thuringiensis strains by polymerase chain reaction product profiles. Applied and Environmental Microbiology 57: 3057-3061.

[9]. Chambers JA, Jelen A., Gilbert MP, Jany CS, Johnson TB and Gawron-Burke C (1991). Isolation and characterisation of a novel insecticidal crystal protein gene from Bacillus thuringiensis subsp. aizawai. Journal of Bacteriology 173: 3966-3976

[10]. Coyle DR, MC Millan, JD, Krause, SC Hart, E.R, 2000. Laboratory and field evaluations of two Bacillus thuringienesis formulations Novodor and Raven, for control of cottonwood leaf beetle (Coleoptra Chrysomelidae), J. Econ. Entomol 93(3): 713720.

[11]. Diaz-gomez, O, rodringnez JC, Shelton AM, Lagunes A, Bujanos R, (2000). Susceptibility of Plutella xylostella (L.) Lepidoptera: Pluetellidae populations in Mexico to commercial formulations of Bacillus thringiensis J. Econ. Entomol., 93 (3) : $963-970$.

[12]. Dominic Amalraj Di Sahu SS, Jambuligam P, Boopati Doss PS, Kalynasundaram M, Das PK (2000). Efficiacy of an aqueous suspension and gramlar formulation of Bacillus thuringiensis (vectobac against mosquito larvae).

[13]. Donovon WP, Gonzalez JM, Gilbert MP, and Dankosik C, (1988). Isolation and Characterization of EG2158, a new strain of Bacillus thuringiensis , toxic to coleopteran larvae, and nucleotide sequence of the toxic gene. Mol. Gen. Genet. 214:356-372.

[14]. Dulmage, H. T. (1981). Insecticidal activity of isolates of Bacillus thuringiensis and their potential for pest control. In Microbial Control of Pests and Plant Diseases 1970-1980 (ed. H.D. Burgess). pp. 193-223. Academic Press, London.

[15]. Federici BA, Luthy P, and Ibrarra JE (1990). The Parasporal body of Bacillus thuringiensis subsp. Israelensis: structure, protein composition and toxicity. In Bacterial control of Mosquitos and Blackflies Biochemistry, Genetics and Applications of Bacillus thuringiensis and Bacillus sphaericus (ed. H. de Barjac and D.J. Sutherland), pp. 16-44. Rutgers University press, New Burnswick, NJ.USA.

[16]. Gill, S. S., Cowles, E. A. and Pietrantonio, P. V. (1992). The mode of action of Bacillus thuringiensis endotoxins. Annual Review of Entomology 37, 615-636.

[17]. Guillet, P., D. C. Kurtak, B. Philippon, and R. Meyer. (1990).Use of Bacillus thuringiensis israelensis for on chocerciasis control in West Africa, p. 187-201. In H. De Barjac and D. Sutherland (ed), Bacterial control of mosquitoes and blacflies: Biochemistry, genetics, and applications of Bacillus thuringiensis and Bacillus sphaericus. Rutgers University Press, New Brunwick

[18]. Haider MZ and Ellar DJ (1998). Nucleotide sequence of Bacillus thuringienesis aizawai ICI entamocidal crystal protein gene. Nucleic Acids Research 16:10927

[19]. Haque M A, Nakakita H, Ikenaga H, Sota N, (2000).Development-inhibiting activity of some tropical plants against Sitophiluszeamais Motschulsky, Coleoptera Curculionidae).J.Stored Prod. Res.,36:281-287.

[20]. Held GA., Kawanishi CY, Huang YS, (1990). Characterization of the parasporal inclusion of Bacillus thuringiensis subsps. Kyushuesis. Journal of Bacteriology 172: 481-483.

[21]. Held GA, Bulla LA, Jr, Ferrari E, Hoch J, Aronson AI and Minnich SA. (1982). Cloning and localisation of the lepidopteran protoxin gene of Bacillus thuringiensis subsp. kurstaki. Proceedings of the National Academy of Sciences, USA 79: 6065-6069.

[22]. Haider MZ and Ellar DJ (1988). Nuleotide sequence of a Bacillus thuringiensis aizawai ICI entomocidal crystal protein gene. Nucleic Acids Research 16: 109-127.

[23]. Herrnstadt, C., Soares, G. G., Wilcox, E. R., and Edwards. D. L., 1986. A new strain of Bacillus thuringiensis with activity against coleopteran insects. Bio/Technology 4, 305-308.

[24]. Hofte, H., and Whiteley, H.R., (1989). Insecticidal crystal proteins of Bacillus thuringiensis. Microbiol. Rev. 53: 242-255.

[25]. Krattiger AF, (1997). Insect resistant in crops: A case study of Bacillus thuringiensis (Bt.) and its transfer to Developing Countries ISSAAA Briefs No. 2. ISSAAA: Ithaca, NY. pp . 1-42.

[26]. Kreig A, Huger A, Langenbruch G, and Schetter W, (1983). Bacillus thuringiensis (Bt.) and its transfer to developing countries. ISSAAA Briefs No. 2. ISSAAA: Ithaca, NY. pp . 1-42.

[27]. Kronstad, J.W., H.E. Scknepf and H.R. Whiteley, (1983). Diversity of location for Bacillus thuringiensis crystal protein genes. J. Bacteriol. 154:419-428.

[28]. Kronstad JW, and HR Whiteley, (1986). Three classes of homologous Bacillus thuringiensis crystal protein genes. Gene 43:29-40.

[29]. Kumar PA,(2002), Bacillus thuringiensis and Insect Pest Management in Agriculture. Proceed.AP Acad. Sci.6(1):29-36.

[30]. Lee CS and Aronson AI (1991). Cloning and analysis of $\delta$-endotoxin genes from Bacillus thuringiensis subsp. Journal of Bacteriology 173: 6635-6638.

[31]. Lereclus, D., Delecluse, A. and Lecadet, M.-M. (1993). Diversity of Bacillus thuringiensis toxins and genes. In Bacillus thuringiensis, An Environmental Biopesticide: Theory and Practice (Eds. P. F. Entwistle, j. S. Cory, M. J. Bailey and S. Higgs), pp. 37-69. John Wiley and Sons, Chichester, U.K.

[32]. Mc Pherson SA, Perlack FJ, Fuchs RL, Marrone PG, Lavrik PB, and Fischhoff DA, (1988). Characterization of the coleopteranspecific protein gene of Bacillus thuringiensis var . tenebrionis. Bio/Technology. 6: 61-66.

[33]. Mulla, M. S. (1990). Activity, field efficacy and use of Bacillus thuringiensis israelensis against mosquitoes, p. 134-160. In H. De Barjac and Sutherland (ed). Bacterial control of mosquitoes and blackflies: Biochemistry, genetics, and applications of Bacillus thuringiensis and Bacillus sphaericus. Rutgers University Press, New Brunswick, K.J.

[34]. Pimentel D, 1991. CRC handbook of pest management in agriculture, $2^{\text {nd }}$ ed., vol.1. CRC Press, Boca Raton, Fla.

[35]. Rahat Makhdoom, Ph.D Thesis,Cloning and Sequencing of the Delta Endotoxin gene from locally isolated Bacillus thuringiensis, Toxic against Spotted bollworm. 
[36]. O.Roth and J.Kurtz,the stimulation of immune defense accelerated development in red flourbeetle (Tribolium castaneum).J.Evol.Bio.21(6),(2008),1703-1710.

[37]. Saiki RK, Gelfand DH, Stoffel S, Scharf SJ, Highuchi R, Horn GT, Mullis KB, and Erlich HA, (1988). Primer-directed enzymatic amplification of DNA with a thermostable DNA polymerase. Science 239: 487-491.

[38]. Schnepf HE and Whiteley HR (1981). Cloning and expression of the Bacillus thuringiensis crystal protein gene in Escherichia coli. Proceedings of the National of Science, USA 78, 2893-2897.

[39]. Sekar V, Thompson DV, Maroney MJ, Bookland RG and Adang MJ (1987). Molecular cloning and characterization of the insecticidal crystal protein gene of Bacillus thuringiensis var. tenebrionis. Proceedings of the National Academy of Sciences, USA 84, 7036-7040.

[40]. Sick A, Gaertener F and Wong A (1990). Nucleotide sequence of a coleopteran-active toxin gene from a new isolate of Bacillus thuringiensis subsp. tolworthi. Nucleic acids Resaearch 18: 1305.

[41]. Shivkumar A, Gundling GJ, Bensen TA, Casuto D, Miller MF and Spear BB, (1986). Vegetative expression of the delta-endotoxin genes of Bacillus thuringiensis subsp. Kurstaki in Bacillus subtilis. Journal of Bacteriology 166: 194-204.

[42]. Sanchis V and Lereclus D (1999). Bacillus thuringiensis: A biotechnology model. J. Soc. Biol. 193: 523-530.

[43]. Thompson, A. T., Schnepf, H, E. and Feitelson, J. S. (1995). Structure, function and engineering of Bacillus thuringiensis toxin. In Genetic Engineering. Vol. 17(ed. J. K. Setlow), Plenum Press, New York.

[44]. Vaeck M, Reyanaerts A, Hofte H, Jensens S, De Beukeleer M, Dean C, Zabeau M, Van Montagu M and Leemans J, 1987. Transgenic plants protected from insect attack. Nature (London) 382: 33-37. 